\title{
Identity and Leisure Time: Aspiration of Muslim Influencer on Instagram
}

\section{Rezki Putri Nur Aini}

Pascasarjana UIN Sunan Kalijaga Yogyakarta

Email: rezkiputri.uinsby@gmail.com

\section{Najib Kailani}

Pascasarjana UIN Sunan Kalijaga Yogyakarta

Email: najib_kailani@yahoo.com

Naskah diterima:19-11-2020, direvisi: 28-01-2021; disetujui: 29-01-2021

\begin{abstract}
This paper analyzes the segmentation of identity and aspirations through the leisure time discourse carried by Indonesian Muslim influencers as a representation of the negotiation efforts of the Muslim middle class society towards the orientation of religious understanding and popular culture within the framework of modernization. The inevitability of differences in religious understanding among these Muslim influencers ultimately influenced them in representing any discourse carried through new media, including leisure time. The neglected issue and case of leisure time become one of the determinants of the new style of Muslim identity when they exhibited their style deliberately through various social media platforms. This study is important to see the extent of segmentation due to new identities and aspirations through leisure time that these Muslim influencers want to channel massively on social media, especially Instagram. This study was conducted through netnographic studies supported by various available relevant literature. The results of the study indicate that there are two major segmentation trends among Muslim influencers today through leisure time discourse on social media, they are committed Muslim influencers and Muslimist influencers, both of them has different identities and new aspirations in leisure time discourse based on contradiction of mutual religious understanding between them.
\end{abstract}

Keywords: aspirations; committed Muslim influencer identity; leisure time; Muslimist influencer; negotiation

\begin{abstract}
Abstrak
Tulisan ini menganalisis segmentasi identitas dan aspirasi melalui wacana waktu luang yang diusung oleh kalangan influencer Muslim Indonesia sebagai representasi atas upaya negosiasi masyarakat kelas menengah Muslim baru terhadap orientasi pemahaman keagamaan dan budaya populer dalam kerangka modernisasi. Keniscayaan atas munculnya perbedaan pemahaman keagamaan diantara para influencer Muslim tersebut pada akhirnya mempengaruhi mereka dalam merepresentasikan setiap wacana yang diusung melalui media baru, termasuk waktu luang. Waktu luang yang perannya seringkali diabaikan, menjadi salah satu penentu identitas gaya baru Muslim menengah saat ini dengan sengaja dipamerkan melalui berbagai platform media sosial. Kajian ini penting dilakukan untuk melihat sejauh mana segmentasi akibat identitas dan aspirasi baru melalui waktu luang yang ingin disalurkan oleh kalangan influencer Muslim tersebut secara masif di media sosial,
\end{abstract}


khususnya Instagram. Kajian ini dilakukan melalui studi netnografi dengan didukung oleh berbagai literatur relevan yang ada. Hasil dari kajian menunjukkan terdapat dua tren segmentasi besar di kalangan influencer Muslim saat ini melalui pewacanaan waktu luang di media sosial, mereka adalah committed Muslim influencer dan muslimist influencer dimana masing-masing memiliki perbedaan identitas dan aspirasi baru dalam mewacanakan waktu luang berdasarkan pemahaman keagamaan yang saling kontradiksi diantara keduanya.

Kata Kunci: aspirasi; committed Muslim influencer; identitas; negosiasi; waktu luang; Muslimist influencer

\section{Introduction}

This article talks about the phenomenon of Muslims influencer segmentation on social media as a form of self-aspiration on the negotiation of the new Muslim middle-class with new media technology through their religious understandings and responses to today's popular culture. The term influencer refers to new Muslim middle-class who are popular through their activities on various social media platforms because of their role has a significant impact on society, especially for the audience.

Leisure time, which according to the general understanding is commonplace and tends to be meaningless, has a significant influence on human life. The study of the middle-class and leisure time has long been a concern of researchers. Wynne (1998) provides an initial view of how the middle-class views leisure and activity and its implications for mobility, lifestyle, and gender discussions. In contrast, Hunnicutt (2006) deliberately explores the beginnings of discussion of leisure from classical Greece and Rome through medieval Europe to the Industrial Revolution, where the study of leisure and its close relationship with the middle-class gradually leads to the assumption that leisure was only entitled to be enjoyed by those who have money. This assumption was also reinforced by Kim (2000, p. 61-81) when looking at the phenomenon of lifestyles and forms of the middle-class consumption in North Korea. He believes there is a dichotomy between the "workers" and the "employed" as a background to the consequences of using leisure activities.

The development was quite significant, leisure time has been considered as one of the shapers of the new Muslim middle-class social identity. This statement was presented by Abdul Rahman Embong (2002a) who detailed several important and most influential aspects in the process of establishing the new Muslim middle-class social identity in Malaysia. These aspects include lifestyle and culture; consist of living conditions, asset ownership, and also forms of consumption to leisure activities.

Ariel Heryanto (2015a) explained in his book, that the lifestyle was formed by modernization which then encouraged the new Muslim middle-class to negotiate and transform their social identity in the form of new freedoms, also as efforts to hunt for new activities or other interesting activities that considered capable for realizing their personal ideals. This statement becomes idea for the mindset in the process of establishing a new Muslim middle-class identity when channeling leisure activities because of the desire to be considered as different by practicing a new and contemporary lifestyle.

Regarding leisure time in Islam, Deeb dan Harb (2013c) critically and objectively, framed the discussion through direct observation in North Beirut. They are able to describe the real situation and condition of the Muslim phenomenon from both the middle-class and the lower-class 
who can freely channel their leisure activities without obstacles. This research was also able to boost the previous initial discussion about leisure activity assumption's that only can be enjoyed by the middle-class.

Furthermore, to explore the relationship between leisure time and the new Muslim middleclass through the representation of Muslim influencers, Abidin (2016a) and Annisa (2018b) managed to narrate by borrowing the term of micro-celebrity, where the influencers managed in wrapping the techniques of working visually and form it in such a way. Gradually their ability becomes an opportunity for certain ideologies to take advantage of the situation through various aspects displayed on social media including leisure time in the name of Islam.

Highlighting the da'wah representation of Muslim influencers, in fact, not all of them use the Islamic frames to preach. This was revealed by A'isyah and Aini (2020a) wherein their writing, they found a variety of aspirations and representations of Muslim influencer figures that were successfully known through nethnographic research. Some of them doing the preach by inviting the audience to be perfect Muslims, but some others also use their Muslim identity with hoods and veils for example, as their identity to show resistance to the traditional perceptions of society towards Muslim woman in Indonesia general.

Therefore, the researcher argues that the new popular culture brought by new media has given birth to various orientations and representations of religious understanding. That understanding then envelops Muslim influencers in Indonesia through the decoration of modernity and a new identities to influence the audience. Without realize it, this phenomenon encourages Muslim influencers to enliven the flow of differentiation in accordance with the understanding of the religion it embraces. This was reflected when these influencers use leisure time and shared through their various personal social media platforms deliberately. Interestingly, the use of leisure time by Muslim influencers has unwittingly doubled in the form of certain aspirations aside from the deliberated of main influences shared with the audience specifically through Instagram.

The presence of influencers in the virtual world like an advisor, solution giver, and even religious leaders 'impromptu'. Grenny (2013b, p. 6) termed that the ability to make changes in human behavior is 'influence', and the person who does it is an influencer or 'giver influence'. These influencers seem to be transitioning into messengers that come from certain ideologies. The emergence of Muslim influencer accounts with religious ideas is filled with da'wah make the role and landscape of influencers currently segmented. This was later justified by Samuli Schielke in Kailani (2020b, p. 8) who stated that in the study of Muslim people's lives in the global realm it is certainly not able to separate them from non-religious references. Predicate as a Muslim becomes very influential in doing or cracking down on something in life. The segmentation that occurs among Muslim influencers is due to differences in orientation and representation of their beliefs towards a religious understanding. In line with Khumairoh's discovery (2018c, p. 3) about the dichotomy of social change in two forms; modernization and anti-modernization phases, both of which are representations of religion and media that are contradicting and facing each other at the same time. This becomes a consequence and response caused by the development of popular culture within the framework of modernity.

Leisure time becomes pretty fooling but interesting because of its non-concrete nature and tends to be overlooked. Similarly, what happens to Muslim influencers, they have unwittingly shared various leisure activities on personal social media accounts based on what they understand and believe in. This research is important to explain the segmentation among Indonesian Muslim 
influencers through the representation of leisure time in various social media platforms, especially Instagram. As a public figure from the scope of the new Muslim middle-class, these influencers were also shaping the new style of Islamic leisure time as an ideological identity based on religious understanding and their response to popular culture in terms of modernization. This phenomenon is seen through various images accompanied by captions shared on the personal Instagram of influencers.

Specifically, this article discusses three questions. First, What is the significance of leisure time as a factor in shaping the new Muslim middle-class social identity in Indonesia about their response to the tangent phenomenon between religion and modernization? Second, How can Muslim influencers represent the new Muslim middle-class on Instagram in carrying Islamic leisure discourse? Third, How each aspiration that wants to be conveyed by committed Muslims and Muslimist influencers in utilizing Islamic leisure discourse through social media?

To answer the questions, this article was divided into six sections. In the first part, it explains the background of this focus of study. The second part of it seeks to investigate the relation between leisure and the new Muslim middle-class. The third part continued with a discussion about Muslim influencers as agents of leisure discourse on social media. The fourth is about the discussion of the identity and aspirations from the first segmentation, here the Muslim influencer group that was only oriented towards self-dedication as devout and pious Muslims. Mentioning committed Muslim ${ }^{1}$ (Bayat, 2007, p.436; Cevik 2016b) influencers by including one of the Muslim influencer figures who are studied directly in-depth based on the typology of symbolic and ideological aspirations through the use of Islamic leisure time to know their patterns of Islam in this digital era and modern Islam. Before the last part, a discussion will be ended by the second segmentation, Muslimist ${ }^{2}$ (Cevik, 2016b) influencers who have contradictions in the orientation of religious understanding with previous segmentation. And finally, this article closed with a conclusion.

\section{Methodology}

This study used online ethnogaphy or nethnography methods (Mariampolski, 2000a, p. 57; Hine, 1999 p. 12; Kozinets, 2009, p. 61) which seeks to combine ethnography and digital technology in viewing and analyzing a social phenomenon. Through searches and observations in several Instagram accounts of influencers observed, researchers record, deepen data regularly until getting a valid and up-to-date analysis. This research also uses library research that takes and processes data through primary and secondary sources of books, journal articles, news records both online and printed, as well as reports of previous research results that have a connection with this research.

\footnotetext{
${ }^{1}$ Muslims have a literal understanding of Islamic law sources and make it as guidance in every aspect of life. Their rejection of foreign influences and traditions (the West), causing modernity to become a threat and potentially weaken the faith. Strong ideas for 'Islam'-ization, tend to lead to political and ideological goals in radical ways, even pioneering the founding of the Islamic state.

${ }^{2}$ Muslims accept modernity and make religion rule of thumb in every line of life. They consider modernity to be a way to discover and form a new identity, with a stylish and fashionable lifestyle but still maintain Islamic values praxis, for example using a veil with a modern way of wearing. Because they think modernity and religion can go side by side, they also believe that every Muslim has authority over himself to do everything according to Islamic rules. They reject the understanding of Islamic orthodoxy which tends not to give a free portion in treating the body. Their position is in the middle between orthodox Islam (Islamist) and Liberal Islam (Liberalist) because of its neutrality and balance of role to bridge significant differences between the two understandings.
} 
Sources of data are obtained directly on a regular basis for activities in the form of stories or videos containing direct conversations from the YouTube channel shared by Instagram influencer accounts because of their "directed" nature, while activities are in the form of permanent posts with the information listed in the description of the image column, will be the primary data source. In addition to related books and journal articles, in other secondary data, this study also uses virtual interviews (direct messages or chat) to several followers of Instagram accounts who were studied through simple random sampling technique. The reason for using this technique is because all individuals who are followers of these Instagram accounts have the same opportunity to be selected as sample members.

By conducting online observations through these interviews, important data will be obtained in the form of followers' lay impressions of what influencers have brought on their personal Instagram accounts. It should be noted that the selection of the Muslim influencer Instagram accounts under study was carried out based on their appropriate predicate and order and has become a trend in recent times. These accounts have also met Instagram's suspended fame requirements with verification and a large number of followers. To make it easier to understand, this study deliberately classifies the Muslim influencer Instagram accounts into two types, there are committed Muslim influencers consisting of personal Instagram accounts @ anisarahma_12 and@ananditodwis as 'halal' couple influencers and Muslimist influencers through personal Instagram accounts@analisa.widyaningrum as one of the Muslim influencers who are more progressive oriented in Islamic understanding.

Leisure Time and the New Muslim Middle-Class

In his writings, Hunnicutt recounts an early understanding of the leisure time terms that could not be separated from "work". The existence of leisure is because the practice and discussion of work at that time became the most important part of people's lives. This is undoubted, where the development of leisure time in line with the Industrial Revolution that requires anyone to "work" especially for the lower-class.

The birth of this practice and discussion about leisure and work also marked the dichotomy that took place between 'Owner' and 'Worker'. The Industrial Revolution that always demanded the public to 'always' working indicated that 'Owner' acted as a 'controller' and 'Worker' as 'controlled' at that time (Wallman, 1979, pp. 1-2). So, that 'Owner' has the free will to control others (workers or slaves), while 'Workers' do not get the same opportunities and must continue to work if they want to stay alive (Chaplin, 1936). In short, there were two categories of social conditions at that time, those 'who were enslaved' and 'who got freedom'. Since then, significant distinctions have arisen in which women and slaves or servants were entitled to be 'controlled' activities (work) while 'Owner' has the right to carry out activities freely.

In this case, the middle-class represents who has 'freedom', so it is because the status as a power holder of leisure time was resulted by their economic ability and the opportunity of time that makes them free to do any activities. Based on Wynne's research $(1998$, p. 2) related to the close relationship between construction and social identity formed by new middle-class communities, it appears that their all forms of actions and activities do have specific objectives, in this case, to establish and reconstruct social identity in society. Embong (2002a, p. 15) details more several aspects that have been utilized in the process of establishing the new Muslim middleclass social identity in Malaysia. These aspects include lifestyle and culture; consist of living conditions, ownership of assets, and forms of consumption to leisure activities they have. This reality because one form of lifestyle and cultural expansion of consumerism in new middle-class society is their tendency towards the utilization of leisure activities (2000b, p. 51). 
Deeb and Harb (2013c) reviewed how the meaning and practice of leisure if negotiated with the geographical and morality of the local people where leisure time was understood and practiced. The orthodox view held that leisure time belonged only to those who have power, leisure time and moneyed, but now was indisputable. Using a background in North Beirut, they successfully uncovered the practices of free use of leisure in Muslim-majority countries under Islamic rule. They find uniqueness in the community dominated by Syi'ah, where there are many opportunities for Muslims to often gather together and make free use of their recreation and leisure time (Deeb and Harb, 2013b, p. 14). Interestingly, the production of such pleasures was coming from an initiative and direction of local religious authorities (Deeb and Harb, 2013c, p. 66).

Measuring indicators that indicate the formation of a new Muslim middle-class as a consequence of stable economic growth in Indonesia, especially since 2001-2010 is the rise of Islamic symbols in various lifelines and the strengthening use of the label 'halal' in various goods and services products (Ridho, 2017, p. 88), where the phenomenon resulted from the condition of the New Order government which for decades was controlled in the restraint of tyranny and lack of Muslims freedom to express their religious behavior (Sakai, 2014, p. 204-205; Hasbullah, 2000c, p. 5). Similarly, Fischer's opinion (2011, p. 173) involved the identity of modern Muslim communities in Malaysia, although not completely applicable, without the need to know the understanding and practice of consumption in Islam, this class of people has contributed to the situation of "markets and countries" in Malaysia.

The tendency to using various products and services by 'halal' labeled and the desire to always hold Islamic values in every action and activity was increasing until it completely changes the lifestyle pattern of today's Muslim middle-class. Unwittingly, Rofhani's analysis (2013d, p. 183) of modern cultural phenomena that distorted for some people even considered as potentially degrading the ethical values of eastern society, but it can be successfully negotiated by the new Muslim middle-class with their efforts in offering that culture Islamically. So, their version of modern Islamic culture was seen to accentuate the values of Islamic life as more modern and not outdated. Thus, Islam formed by the new Muslim middle-class is considered quite friendly in greeting globalization and modernity because of its progressive nature.

The dynamics of social and cultural conditions created by the new Muslim middle-class are very suitable if explained through three factors, which all three play an important role in the process of producing culture, including ideas, activities, and artifacts. Rofhani's view on these three factors proves the role of the new Muslim middle-class towards the formation of a new culture which also includes the originating of ideas and the use of leisure time to carry out various activities in society. These activities will later produce artifacts or important and influential works in the process of creating a new culture.

If seen based on the frame of reference that became the basis of its formation, it is necessary to classify Islamic leisure time into two types, both 'shaped by Islam' and 'shaped by Islamic modern culture'. Islamic leisure time shaped by Islam is a leisure time that is formed clearly and concretely by normative Islamic rules based on the main sources in Islam such as the Qur'an and Hadith, which also involves the role of five pillars of Islam, three of it indicate a tendency in the use of leisure, such prayer, fasting, and hajj. Welch in Martin and Mason (2004, p. 8) explains that prayer is a daily ritual of worship that is required to fulfill it at all times, fasting is a time to refrain from hunger and thirst and be able to resist all passions, while hajj is a time when Muslims are encouraged to travel to the Baitullah (Mecca) and perform worship for a few days and even weeks. The three pillars of Islam are loaded with indications of the role of Islam formally when interpreting leisure time and regulating it. This is the case with special worships and other big days 
such as congregational prayers for Muslim men on Fridays, Eid al-Fitr, and Eid al-Adha, where all of them unwittingly contain the significance of the use of leisure time in line with standard Islamic teachings.

In contrast to the understanding of Islamic leisure shaped by Islamic modern culture, which is more focused on the involvement and role of the new Muslim middle-class as actors in building new cultural patterns of society. As it is called, shaped by Islamic modern culture, this leisure time was formed due to the development of modern Islamic culture by the new Muslim middle-class who still want to exist and be viewed today even though its identity as a Muslim was previously known with traditional and outdated. Some forms of Islamic leisure time shaped by Islamic modern culture; halal travel on behalf of umrah or hajj plus, pilgrimage tours, traveler hijab trends, attending science and study assemblies, and Islamic philanthropy. These forms have no legal basis like Islamic leisure time shaped by Islam so, the application seems forced only to look capable and exist as a new Muslim middle-class. Therefore, it is justified by Abdurrahman (2009a, xiii), about how the new Muslim middle-class today has embraced the piety of a new style by wanting to show themselves as pious and modern people.

\section{Muslim Influencer: Representation of the New Muslim Middle-Class}

Muslim influencers as an actor supporting Islamic leisure discourse are indirectly able to influence and have a significant effect on the audience in the acceptance of intended various purposes and objectives. Muslim influencers portrayed by social media are who do not awkwardly practice modern culture with an oriented middle-class lifestyle. The culture and lifestyle that thought the West as most civilized, the culture of the elites, and the learned become triggered cultural hegemony that gave rise to relative identity (Rofhani, 2013c, p. 194). This identity encourages the search for personal identity as the main goal of achieving modern life and can determine the purpose of a particular action based on symbolic identification at the same time. They try to build their identity symbolically through various social media platforms by synthesizing culture, emerging the more modern and outdated Islamic culture, but still in syar'i status. Seemingly agreeing on Ward's understanding (2020c, p. 20) of a 'harmonious' meeting between religion and the media, both of them are now intertwined in serving many purposes and can jointly together to survive toward the wave of modernity.

Micro-celebrities (Beta, 2019, p. 7; Abidin, 2016a, p. 86; Baulch and Parmiyanti 2018a, p. 2; Annisa, 2018b, p. 39) becomes one of the important elements in producing Islamic identity symbolically among influencers. Annisa believes that the Muslim micro-celebrities represented by Muslim influencers can attract the support of Muslim audiences, even forming the Islamic community or public itself (Annisa, 2018b, p. 38; Hasan, 2009b, p. 236-237) which can certainly come from various communities, especially the new Muslim middle-class. In the end, this power of micro-celebrities who tasked with translating various forms of influencers representation through images and stories, narrated by or focused on their faces, voices, and bodies (Ward, 2020c, p. 8).

Interestingly, micro-celebrities utilized by influencers always put forward intimacy or closeness to their private lives to be shared into public spaces and become consumption there (Raun, 2018d, p. 99-100). This fact becomes an attraction for their followers in every post of their photos, captions, and stories on social media. In framing the closeness between influencers and followers, micro-celebrities must make it easier for viewers to truly realize the reality of symbiotic relationships with fans. When social media has served as a self-reflection, it will easily include influencer's ideas and messages veiled with the 'guise' of all social issues in life shown through 
various uploads. Thus, the emotional connection presented between them was created by religious representation in the media framed by personal narratives and facilitated by the choice and creativity of mediated individuals (Ward, 2020c, p. 23). In other words, social media will act as an intermediary that becomes a bridge across influencers to convey its purpose to followers in this case or its terms according to Nancy K. and Danah (2012, pp. 320-329) mentioned by socially mediated publicness.

By carrying the discourse of piety through every performance uploaded on social media, the Islamic public can also be formed with various purposes outside the orientation of religiosity. Most of them even just want to boost popularity in realize commercial goals. Here then Muslim millennial youth take their active position and become 'victims' when faced with this situation.

About leisure time among Muslim influencers and their followers, was closely related to the mindset and lifestyle of the new Muslim middle-class today. Researchers from Middle-Class Consumer Studies, Yuswohady (2014b) divided the Indonesian Muslims Middle-Class into four figures, there are apathetic, conformist, rationalist, and universalist.

In this study, discussions will be focused on two new Muslim middle-class figures who are trending in every social media upload today, especially Instagram. Both trends are conformist and universalist figures, where are seen competing in the fight for existence to instill their ideas in the virtual world. Conformist figures are generally obeyed worship and tend to apply Islamic values normatively. They are also less open to foreign cultures outside Islam (West) because of the limited insights and traditional attitudes that they always put forward. Meanwhile, universalists are a more flexible type, although they believe in Islamic values is more important, they are also very open to cultures outside of Islam and have broad insights and 'literate' technology. They tend to accept all forms of difference and uphold the universal nature of humanity.

The influencers from various Muslim middle-class backgrounds wrap up their intentions, goals, and ideas then share all of them to the followers by the various forms of leisure time through various uploads and captions. So, this article will focus on two types of Muslim influencers who would be appropriate for the following mentions. The use of "Committed Muslim" influencers is appropriate to see the tendency with conformist influencers, while the term "Muslimist" influencers are very appropriate to call universalist influencers.

\section{Identities and Aspirations of Committed Muslim Influencers: Self-Promotion As a 'Kaffah' Muslim³ $^{3}$ (Kompasiana.com, 2013)}

As a Muslim-majority democracy, the discussion of the relationship between piety and religious information is interesting to discuss because the availability of various variants of Islam was influenced by various segments of society and closely related to how all of them want to reveal their identity (Ridho, 2018d, p. 150).

The main and most common identity displayed by a pious Muslim is the use of syar'i clothing and even a veil covering the face for women and "isbal" pants or long beards for men (Addini, 2019a, p. 113). This identity was very precisely constructed because clothing is an identity to edifying power over one another. In his study, Brenner (1996, p. 673-674) concluded

${ }^{3}$ The real Muslims or Muslims who practice the teachings of Islam in every aspect of life. A Muslim cannot be said to be a 'kaffah' if he has not carried out the teachings of Islam in all aspects of his life. Muslims who are 'kaffah' does not stop at the saying of creeds or religious rituals only but have explored the substance of the creed and the rituals. 
that the use of headscarves or head coverings for women was a firm effort of modernists to be free from the old tradition of wearing veils or from elements of Western modernity in the late 1980s. This discussion gradually proved that the identity of the Muslim group is trying only to build a symbolic identity (Addini, 2019a; Yusuf, 2019c, p. 169-171). It is evident that by presenting themselves in front of an audience as symbolically pious, besides gaining authority and recognition of the body from one another and the group, easily they can also influence the audience that has perfectly imaged when looking at them.

Then, this potential phenomenon was utilized by various popular Muslim influencers in Indonesia to display their identity on the cyber stage as a pious figure and 'Kaffah' in carrying out religious orders. One of the things that will be studied and described in this article is the married couple 'hijrah', Anandito Dwi Sepdiawan and his wife Anisa Rahma Adi. The selection of two figures as the subjects of discussion was not without reason, the couple was considered to be a committed Muslim influencer who currently has many followers and mostly comes from millennials 'hijrah'. They have also incarnated like speakers and motivators 'impromptu' and always ready to be invited in various seminars with Islamic titles.

Anandito is an Indonesian religious singer who joined one of Indonesia's most famous new music groups, ADAM. He finished his bachelor's degree at the University of Education Indonesia through the study program Management Resort \& Leasure. As a musician, he has spawned several works of Islamic music, all of which are titled romance. In addition to being a singer, he has also starred in various forms of short films broadcast on YouTube and two feature films, such 212: The Power of Love in 2018 and 100\% Halal in 2020 ('Anandito Dwis', 2020). Unlike his wife who is a famous former Indonesian girl band, Cherrybelle ${ }^{4}$ (Kompas Cyber Media, 2020) (Kompas Cyber Media, 2020). Anisa is known since she started her career as a member of a girl band that is attached to miniskirts and her cute and adorable look. Similarly to Anandito, Anisa also has acting experience in portraying several films that she has starred in. However, in the midst of Anisa's fame, precisely in 2013 heard the news of her resignation from Cherrybelle on the grounds of wanting to continue her education, considering that she had also sat in the final semester at the first level (WowKeren.Com, 2020). Since then she began her transformation to emigrate to wear hijab and syar'i clothes.

${ }^{4}$ Teenage vocal group debuted on February 27, 2011, and consists of nine women who also have the ability to dance and sing. At the beginning of its formation, the group that is familiarly called 'Chibi' consists of Angel, Anisa, Cherly, Christy, Devi, Felly, Gigi, Ryn, and Wenda. The group has also made history as the only girl group to hold 33 provincial concerts in 31 days held from April 30 to May 30, 2013. 
Figure 1. Transformation of Anisa Rahma Adi's appearance

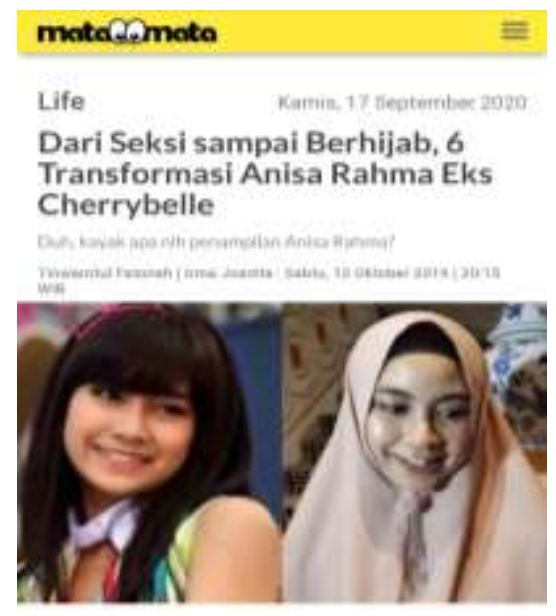

Source: Courtesy of www.matamata.com

(MataMata.Com, 2020)

'Hijrah' which was originally interpreted as a personal spiritual change, now beginning to shift and become communal consumption. Today, 'hijrah' becomes a social trend for the Indonesian Muslim middle-class in general. Maryati in Addini (2019a, p. 110) states that a trend is a tendency to up or down in the long run against the average of a change over time. Thus, a phenomenon can be referred as a trend if its existence gets appreciation or support and becomes a communal interest

Actually, as a committed Muslim who have a closed tendency to the understandings of Islamism, the behavior identity shown follows the rules of fundamental Islam. Generally, Heryanto (2015, p. 60-61) summarizes the term Islamism which is appropriate to describe the phenomenon of this group in Indonesia, as a social movement that calls for and maximizes the application of Islamic teachings (as understood by its followers) as widely as possible in public spaces and it is not limited to the application of sharia as the basis of the government of a nationstate. For further, Bayat (2007a, p. 14) explains that Islamism appears as a term to discuss selfdistrust, to mobilize ambitious middle-class groups, those who feel marginalized by the process of economic, political, and cultural domination in society.

Completing Bayat's explanation, A'isyah and Aini (2020a, p. 7) consider that exposing religions to the public domain through the media is a consequence of the weakening of religious existence in the wave of modernity. The motivations of influencers like Anisa and Anandito show their religious expressions because they were not able to present themself in terms of secularism. However, in practice, both religious expressions on social media have become a new formation in the religious agenda, to be able to attract the trust of the audience, about the lure of a miracle, a blessing of God, but interspersed with the marketing of certain products related to their economic benefits. This reality was also recently approved and further developed by Pete Ward (2020c, p. 26) in his book "Celebrity Worship". The excessive of new media adoption and less value of religiosity was then diverted to seek religious authority.

Holding the status of a young Muslim couple 'hijrah' by galvanized claims of his marital identity as "Dream Wedding", Anandito and Anisa Rahma managed to gain sympathy in the hearts of the audiences or followers, especially among the millennial Muslim middle-class. Actually, the two young couples who are crowded with various job offers as 'hijrah' motivators today began to 
know each other and acquainted after their met in one of the shades of the Islamic musical short film project which aired on Youtube. Both of them were co-stars in the film produced by Abay Adhitya or often called Kang Abay where the project of "singlelillah" which he initiated loved by many favored millennial Muslims at that time (Jabar Tribun News, 2018).

These two couples always perform together by showing how romantic and happy when a pair of young men women have bonded in a 'halal' love affair, making them into the spotlight of millennial audiences who also want to have similar luck. Not only that, what makes them more popular among Muslim millennials was the process of 'hijrah' by his wife. Ex of "Cherrybelle" girl band member who has been known in skimpy and sexy clothes for her stage performances has performed 'hijrah' and also enlivened the 'hijrah' debate among academics. The 'hijrah' symbolic Muslim identity that was built, has bewitched millennials to make it as a public role model on social media or Muslim influencers. Similarly, her husband, Anandito who started his career as a religious singer. Not much was known about him before he met Anisa in the "Singlelillah" film project. In short, the name and identity of a Muslim influencer attached to him were obtained after he successfully married Anisa Rahma, an ex-girl band member of 'hijrah' artist. In other words, both received recognition and identity as Muslim influencers did not exist from the provision of their Islamic religious knowledge but come from of audience's understanding of 'hijrah' that was interpreted symbolically by changing the self-appearance to more syar'i applied and become a guide in life to be a 'Kaffah' Muslim.

As Muslim influencer couples, Anisa and Anandito were consistently encourage followers to adopt what they believe in and do. In this case, they use the issue of love and 'halal' relationships, the display of syar'i clothing to friendship (community) that can lead themselves to become a better person. These two identical couples always portray the figure of both as the perfect couple who should be an example for millennial Muslims.

Beta (2019b, p. 10-11) describes two ways religious influencers convey their identity as devout, ideal, pious and 'Kaffah' Muslims. First, they use verses of the Qur'an and Hadith with constructive captions to explain their meaning and connection to an uploaded message. Second, use Muslim influencers to convince a message or intention, where the influencer must certainly be able and ideal in showing the side of piety and it's 'Kaffah' in Islam.

Whatever the two 'hijrah' couples uploaded on their respective Instagram accounts was always be the spotlight. Finally, the life of a young 'hijrah' couple who are Islamic, happy, impressed, and far from being exposed to family problems, became a gift obtained when someone performs 'hijrah' by changing to the syar'i style. This doctrine is further strengthened and showed by all their activities who are always together, side by side at every moment, also unforgot to always wear syar'i fashionable clothes. On holiday occasions for example, they proudly and happily show off every precious moment while traveling with the lure of their 'halal lover', even when at sea and beach. Anisa does not hesitate to keep wearing the syar'i hijab and long robe touching the land. 
Figure 2. The moment when two couples spend time together
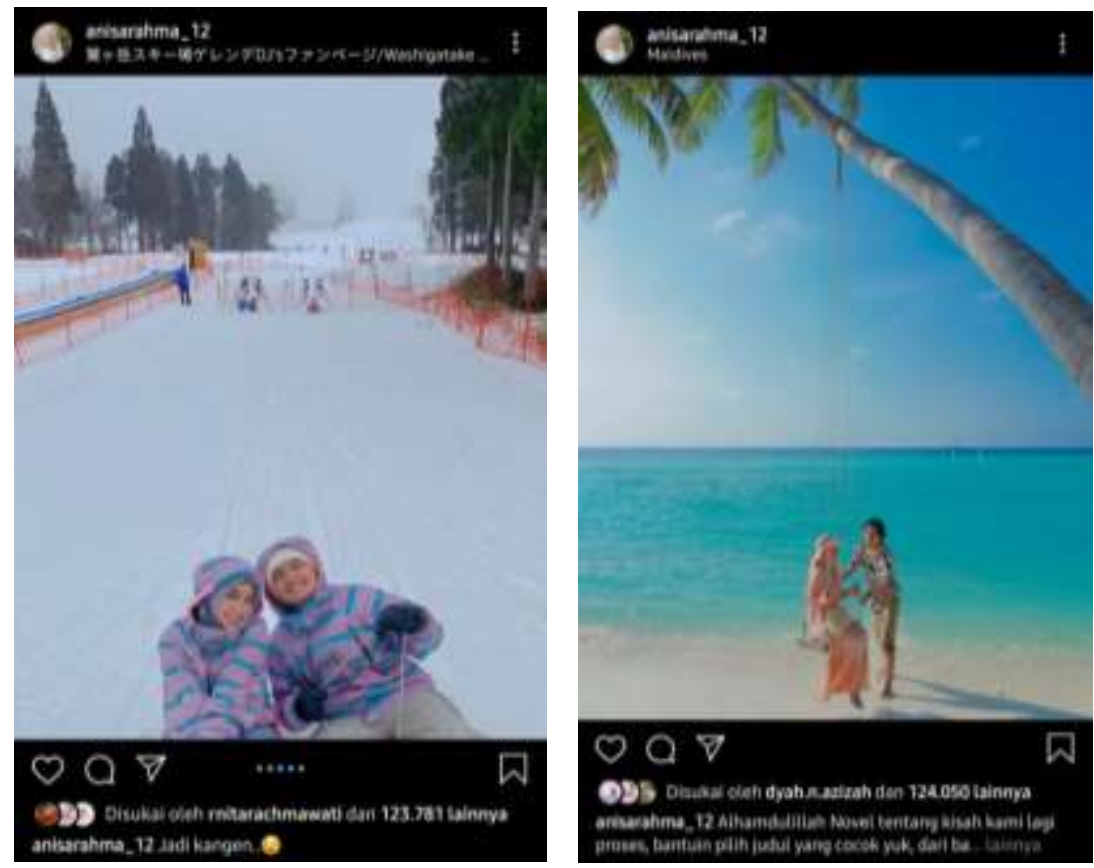

Source: Courtesy of @anisarahma_12 instagram account (Anisa Rahma Adi (@anisarahma_12)・Instagram Photos and Videos, 2020)

Not only are holidays synonymous with fun or refreshing, but they also often take the time to be a peakers at various Islamic events that are targeted again among millennials. In addition, to support their prestige as Muslim influencers, they are also active in several well-known Islamic philanthropic programs that often appear to promote their programs on Instagram feeds.

Figure 3. Online posters of Islamic event when Anandito and Anisa become speakers
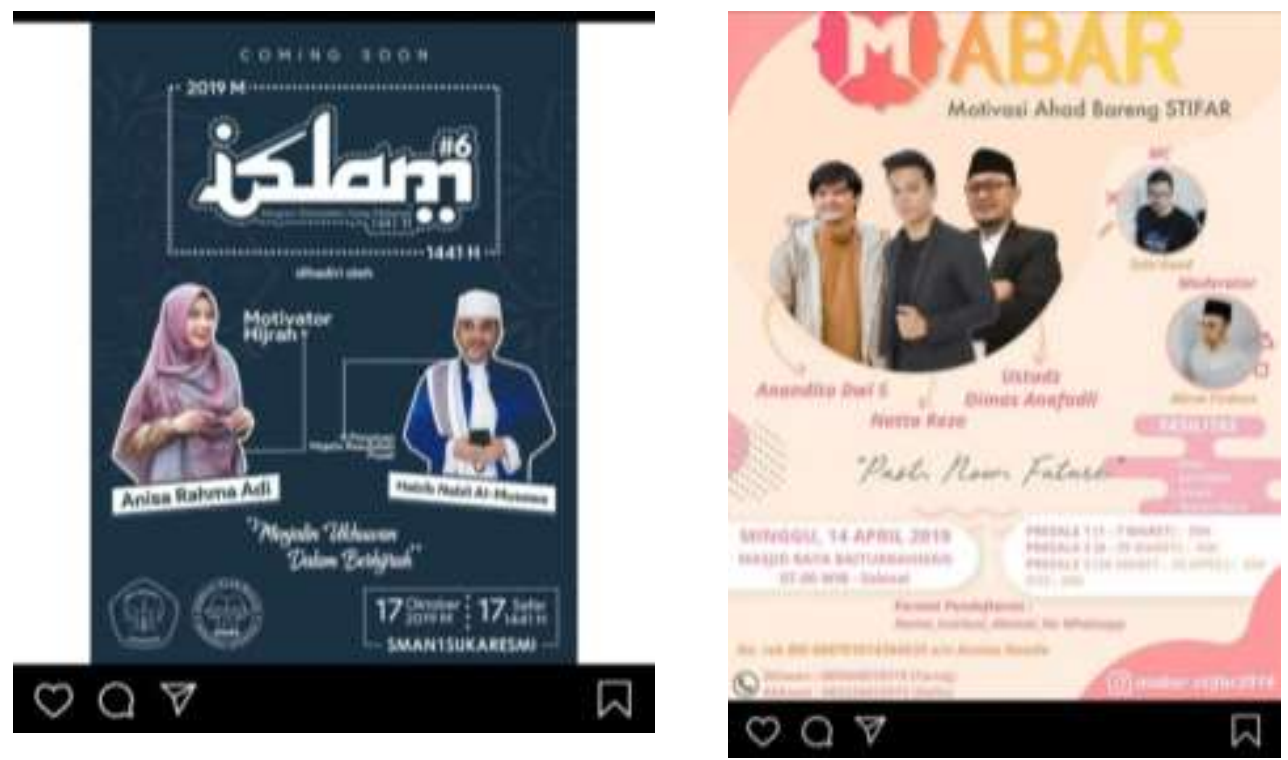


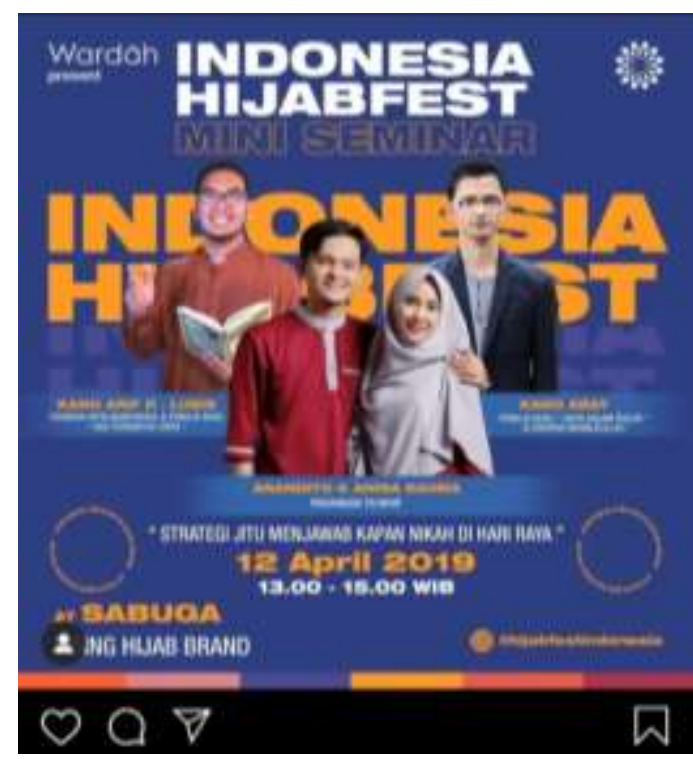

Source: Courtesy of @anisarahma_12 and @ananditodwis Instagram accounts (Anandito Dwis (@ananditodwis)・Instagram Photos and Videos, 2020; Anisa Rahma Adi (@anisarahma_12).Instagram Photos and Videos, 2020)

Figure 4. Anandito and Anisa's participation in Islamic philanthropy program

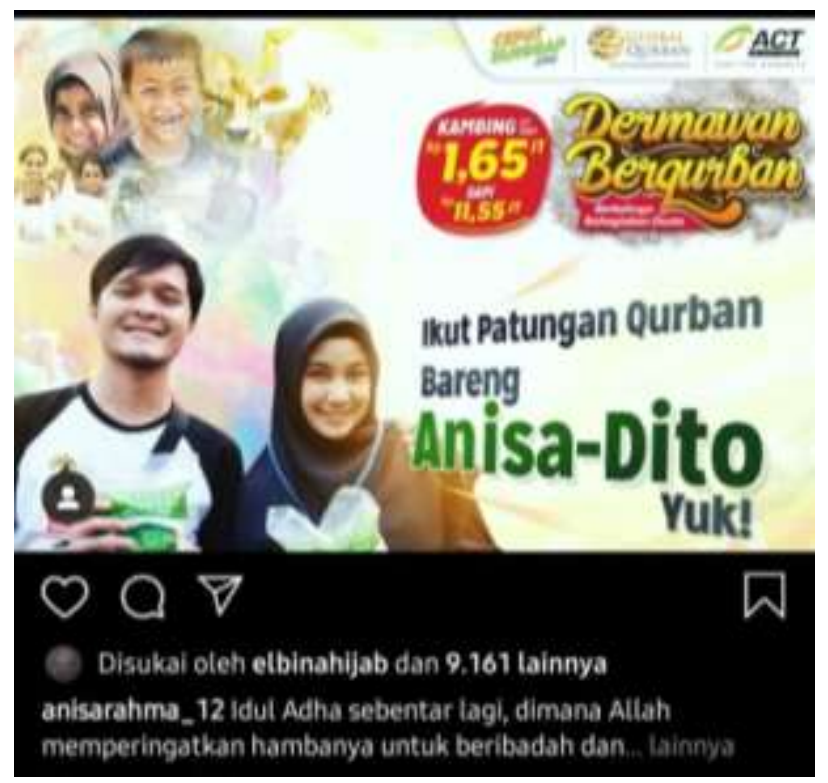

Source: Courtesy of @anisarahma_12 Instagram account

(Anisa RahmaAdi (@anisarahma_12)・Instagram Photos and Videos, 2020)

This phenomenon certainly has a significant effect on followers who idolize them, especially in utilizing their leisure time. With real examples demonstrated by these two influencer couples, Muslim millennial followers are indoctrinated to carry out a similar lifestyle. Starting from changing their appearance to be more syar'i, visiting or looking for a 'halal' beauty clinic as proof of 'real adoption' of what is suggested by their idol figure, and willing to take the time for simply 
refresh or travel whether it is purely for refreshing or just for the needs of a status update on a personal Instagram account and also attending events in which there are both couples as speakers.

The symbolic image built by these 'hijrah' couple Anandito and Anisa Rahma through leisure time discourse with Islamic breath and does not violate Islamic religious norms, it seems to shifted and narrowed the understanding of leisure time itself. Leisure time, which was originally understood as an activity to refresh the tired mind of the frenetic work, now interpreted as an activity closely related to religious understanding. As if to be a true Muslim, the use of Islamic leisure time becomes mandatory law for them. In addition, because this popular culture makes Islamization and commercialization as two inseparable inevitability (Rakhmani, 2016b, p. 61-62), this opportunity is utilizing by committed Muslim influencers to reap the benefits in terms of image and material existence. In other words, Islamic leisure time can be understood as an appropriate golden opportunity to insert the ideological interests of committed Muslim influencers as a means of forming a social identity in society.

Mietzner and Muhtadi (2018d, p. 480) acknowledge that most of the influential Indonesian Muslims, if in this article, are represented as Muslim influencers come from conservatives and the new middle-class, including artists or 'hijrah' celebrities, who usually represent a moderate and progressive perspective in religious understanding. Here it appears that the side of Islamism they bring is not like the traditional understanding of Islamism in general without tolerance and rejects modernity, but vice versa. These committed Muslim influencers incarnate as a milestone of the new branch of religious authority by bringing new different perspectives and faces from their predecessors while still carrying the motto of an ideological approach that claimed as the truest way to be a 'kaffah' Muslim figure. Moreover, their footprint was increasingly supported by the growth of available and easily accessible to various digital platforms facilities in Indonesia. This fact was like approving Kailani and Sunarwoto's thesis (2019d, p. 206) about the happening of Islamic televangelism impact in Indonesia today. In short, they have created a new form of Islamism through the bridge of Islamism idea itself in responding to Islam and modernity.

Through the Islamic leisure discourse formed in such a way, the committed Muslim influencers are trying to show that the advantage of leisure time utilizes with useful way and unclear purposes, by still maintaining a kaffah Muslim identity as well as modern with all their distinctive lifestyles, they may just follow the studies organized by various science assemblies, especially their communities held, where the themes that will be discussed always taken from selected themes and attracted millennials, for example about the soul mates theme. Another form of their version of leisure is also in recreation way, by still using the "Halal Dating" motto and also doing holidays with halal couples to various destinations that offer halal facilities or traveling abroad to visit Islamic historical sites.

\section{Identities and Asprations of Muslimist Influencer: A New Form of Feminity Reasoning}

The connection between the discussion of leisure time and gender position seemed can not be missed when discussing the lives of Muslim influencers. Indirectly, their post of leisure time activities on Instagram forcing the public to produce a wide range of speculations. Starting from a life surrounded by all luxury and success, independence, to busyness as a Muslim female influencer as well as an entrepreneur or founder of a consulting agency engaged in community development. Certainly, this situation jumps away from how women traditional stereotypes in society who are said to be inedible to get it all. Because a woman would have more important role as a secondary actor and be behind a successful man who became part of human history (Carrieri, Diniz, de Souza, \& Menezes, 2013a, pp. 283-284). This is because women are regarded as 
"something else" in the social structure of society and do not have the same privileges as men, so only men can represent a universal figure for the general public environment (Barlas, 2001, p. 16; Braidotti, 2002b, p. 350).

Apparently, the inferior views of women are step by step can be sidelined by the stretch of modernism that increasingly radiates the social structure today. Women today, managed to show their courage in fighting the negative stigmas that have been entrenched in society. The same situation was experienced by Muslim influencers with Muslimist-oriented, they use this digital moment as a way to show real identity in counter this inferior views and not hesitate to publish them.

Through the mechanism of leisure time discourse, unwittingly, they have given the audience a clue that women will have more freedom of space to do any activity when she is can show her identity as a free career woman, an independent and balanced mother with her man or husband.

As did one of the following Muslimist influencers, where she was a businesswoman, the consulting institution owner, mother, and wife who was now known on various social media platforms as a successful young Muslim inspiration figure, Analisa Widyaningrum. Analisa used to be an avid, tenacious, educated woman and not from a wealthy family. She got the predicate of Muslim influencer since her emigrating and changing the appearance in fashion style to be Islami.

Figure 5. Analisa Widyaningrum Instagram account

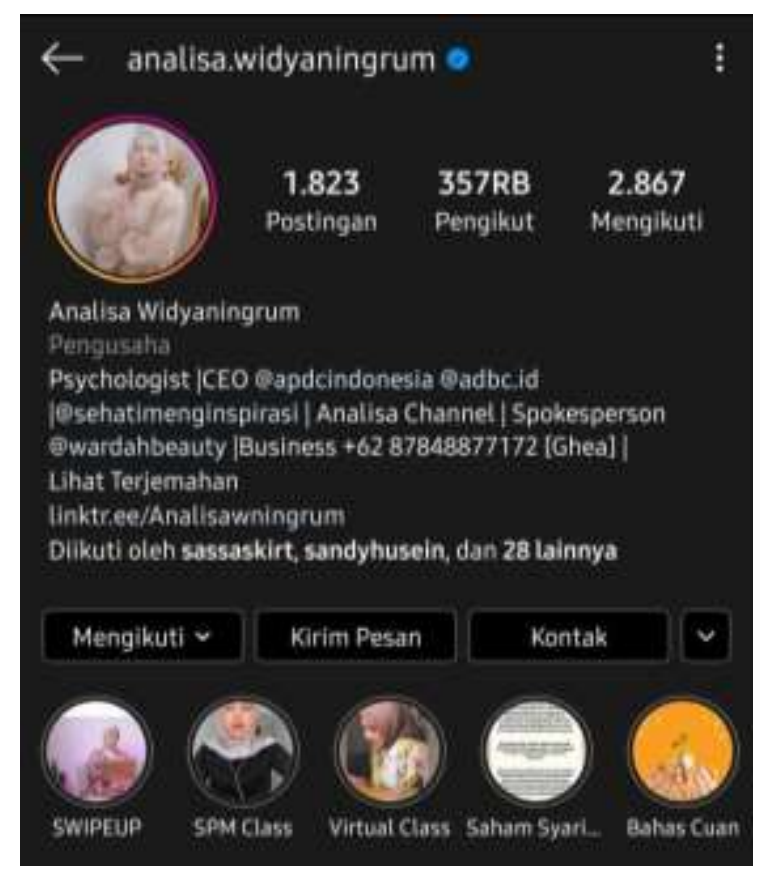

Source: Courtesy of @analisa.widyaningrum Instagram account

(Analisa Widyaningrum (@analisa.Widyaningrum)•Instagram Photos and Videos, 2020) 
Figure 6. When Analisa become a guest speaker on one of the television talk shows and she has not veiled yet (Sarah Sechan, 2013)

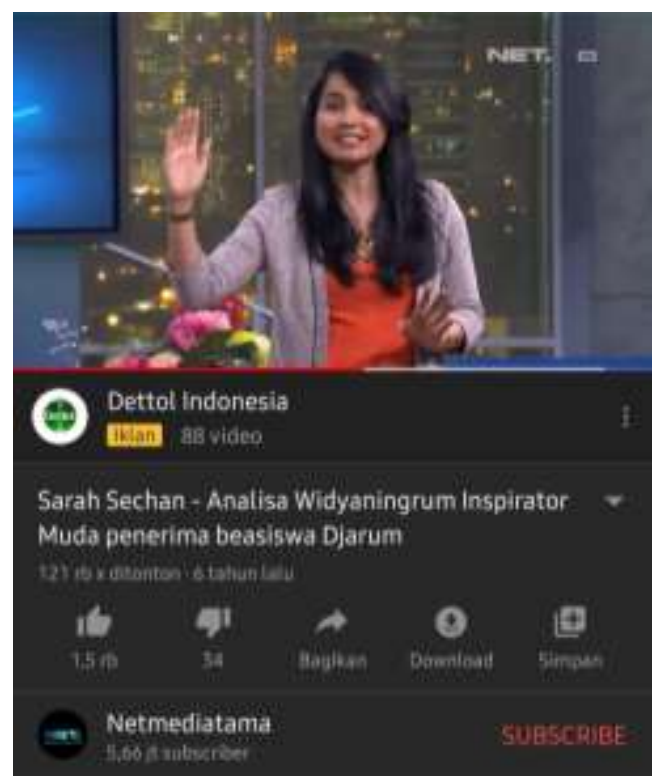

Source: Courtesy of @ NetmediatamaYouTube channel

(Sarah Sechan - Analisa Widyaningrum Inspirator Muda Penerima Beasiswa Djarum, 2013)

She was a successful alumnus of Gadjah Mada University and currently active as a moderator in MPR RI Goes to Campus, which is a discussion activity between members of the Indonesian People's Consultative Assembly (MPR RI) with academics, students, and the public. In addition to carrying out her duties as a psychologist at Jogja International Hospital and Homeschooling Anak Pelangi, she also teaches at several private universities in Jogja, flight attendant schools, and trainers in several corporate agencies. Not only that, the influencer who was born on January 31, 1989, has intelligence since college. She was known as an accomplished student (jadiberita.com, 2017). Reporting from wolipop detik.com, Analisa was the recipient of Djarum Beasiswa Plus 2009 and has been a Language Ambassador, as well as being an Indonesian delegate in the ASEAN Youth Friendship Network in 2020 (Putri, 2020).

Based on the news reported by Femalepreneur.id (Femalepreneur Indonesia, 2020.), Analisa was included in one of the 12 influential female influencers in Indonesia, who has a considerable professional consulting agency in personality development, in line with her scientific field, Psychology. APDC or (Personality Development Center Analysis) which she founded in 2015 was intended as an integrated personality development center and not only provides training programs, but also combines it with values and psychological aspects (Analisa Personality Development Center (APDC) | LinkedIn, 2015). With her personal branding ability, Analisa can attract the audience to follow life tips from the psychologist's view through her Youtube channel. So, it is no wonder if she has 335.000 subscribers now ((431) Analisa Channel - YouTube, 2020).

Like the other influencers who have a family, Analisa often shares beautiful moments on Instagram with her husband and two children when vacationing somewhere or just chatting at home. However, despite this fact, as an influencer who was quite in demand nowadays, her Instagram account does show more how she existed to be a career woman, a stylish, smart, and beautiful mother and wife and also make sure herself to still become shalihah woman. 
Figure 7. Analisas's togetherness with her family on vacation

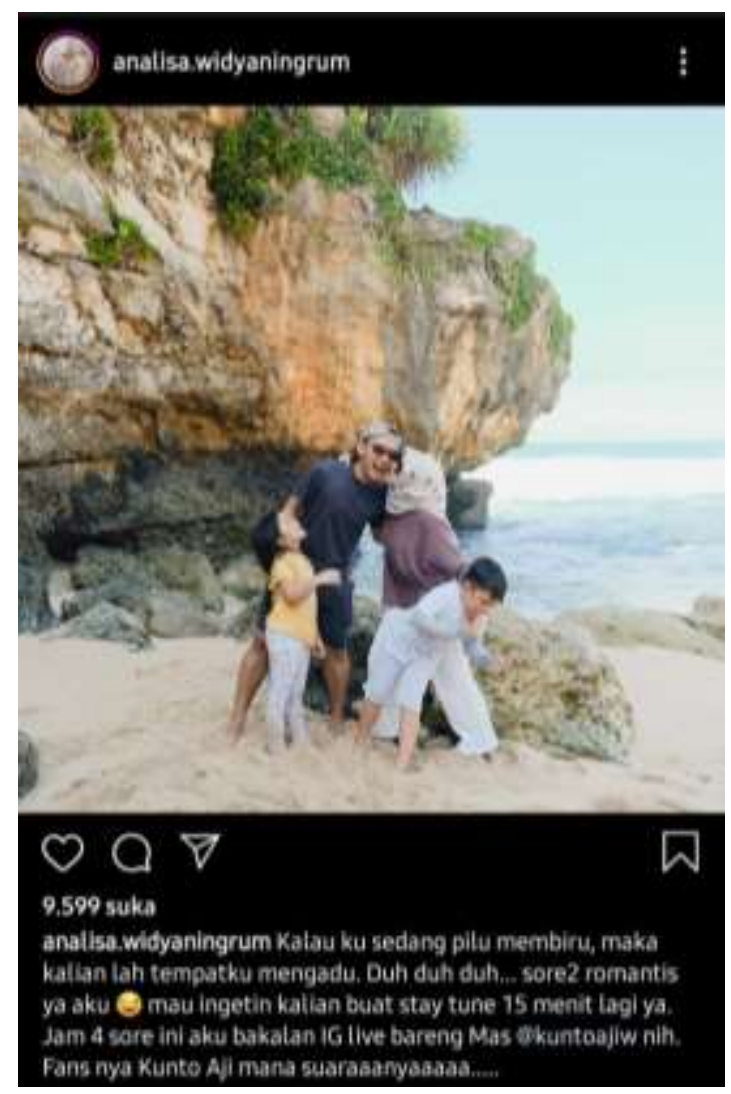

Source: Courtesy of @analisa.widyaningrum Instagram account

(AnalisaWidyaningrum (@analisa.Widyaningrum)•Instagram Photos and Videos, 2020.)

Muslimist influencer like Analisa, where she was more involved in the business and entrepreneur field can be seen from her mindset in responding and 'chewing' religious understanding. She does not look at religious understanding radically and utilize Instagram account as a form of da'wah and aims to invite the audience to be more Islamic like committed Muslim influencers. In addition, her decision to keep the distance from the da'wah field even though her identity as a Muslim influencer, becomes one of her future-oriented think manifestations. 'Keep the distance' does not mean relying on her status as a Muslim and the hijab stuck on the head just to maintain her existence as a Muslim influencer, but she still hold on her goal as a Muslim who always try to multiply religious knowledge and give benefit to the family and also the surrounding environment. This is evidenced by the following image, where Analisa tries to answer a question from one of the follower's comments on Instagram based on her religious understanding. 
Figure 8. One of Analisa's caption to answer the audience's questions based on her existence of religious understanding as Muslimist influencer

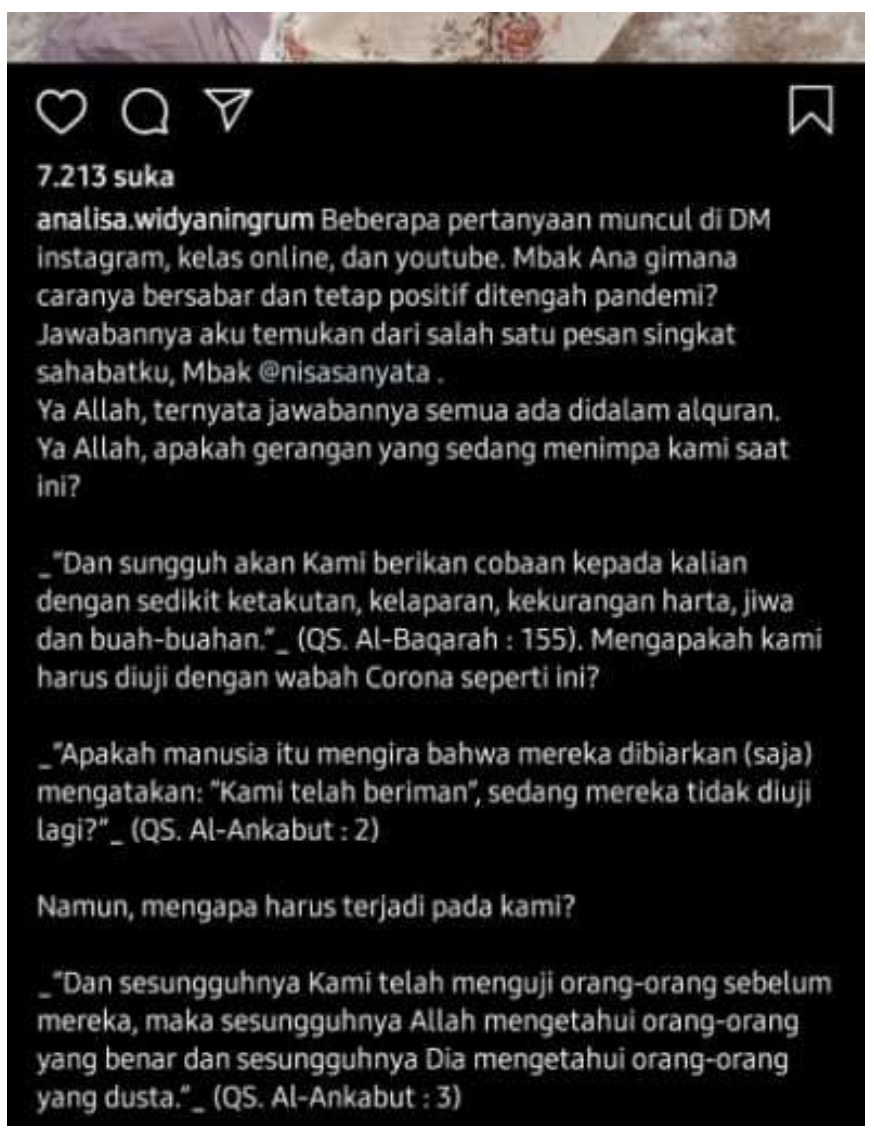

Source: Courtesyof @analisa.widyaningrum Instagram account

(AnalisaWidyaningrum (@analisa.Widyaningrum)•Instagram Photos and Videos, 2020)

Uniquely, although Analisa does not have an orientation in the field of da'wah, but it looks like if she has her own version of non-religious oriented da'wah which when analyzed further, this assumption is very closely related to the use of her leisure time. If noticed in some of her Instagram posts, she often shares photos of togetherness with her family both while on vacation abroad and some tourist destinations or just spending time together at home, being one of the speakers or hosts in a formal event, and sharing various videos of her flagship tips on mental psychology or such which become the most posts on her Instagram account. Indirectly and unwittingly, Analisa wants to try and communicate her leisure activities to the audience through her own version of da'wah with several activities that are out of her 'work' time. So it is not surprising if the activities position were only regarded as an activity to fill her leisure time, but because some of these activities are intermediaries producing co-workers, so she believes that "her leisure time is her 'work' too".

As a successful Muslimah influencer, Analisa tends to have her own role in her family even in the virtual world that raised his name. Nowadays, she was known as an independent, beautiful, rich, successful, family-loving woman, and seems to deserve equal to her husband who has similarities in the level of strata education as her private information post on Instagram. This was reasoned because Analisa's husband, Muhammad Aji, does not have a 'stage' on social media so he has never been exposed by the media crew. Heryanto (2015a, p. 27) sees that so far the several aspects of various conceptual issues in society such as those related to modernization, development in a country, economy, religion, and even corruption have always been seen as a 
problem of masculine people. Not only that, in the academic field there is also a difference between men and women by positioning women in the next rank after men, both in private and domestic fields, which is the main space for leisure time spent through the intermediary of mass media, entertainment, and popular culture. Along with this situation, there are forms of a dichotomy between masculine biases identified by newscasts and feminine through soap opera broadcasts, even of 'women' serious mass media and magazines. However, because of the widespread from screen culture in this era, the division of dichotomy was unstoppable and undirectional to encourage the emergence of various identity politics, which difficult to separate from the society various desires of joy and entertainment, and also legitimacy for the enjoyment of life and things which leads to the feminine value (Heryanto, 2015, p. 27).

Success in doing business, as she illustrates in every Instagram post, has made her known as a responsible mother and wife. However, as a career woman, Analisa does not impose home responsibilities on her husband or housekeeper. But, she and her husband were committed to a career together and will retire at the age they have agreed to. Therefore, the advantages and disadvantages of both of them regarding the household have become a definite consequence that must be faced together. They just want to face every problem together until can be passed well. This argumentation was reinforced by their statement on "Analisa Channel" ((431) Analisa Channel - YouTube, 2020). where both of them look compact in handling all household affairs, especially children. It appears that Analisa does not want her position to equal with her husband or even rival him, she prefers to cooperate with him in taking care of the household in accordance with her nature as a woman, mother, and wife. Moreover, in one of the statements she once said that she still needs a support system from her husband to face every stage in her life. So, in this case, Analisa only wants to show her identity as a strong Muslimah, hardworking, and successful mother of two children, as well as a wife for her husband.

This phenomenon seems approving Saskia Wieringa's observation (2015b, pp. 27-44) about 'gender harmony' and the growing trend of 'sakinah family'. In that sense, modern Muslim society is no longer lost by worldly success even though the achievement of it still important for them. Muslims like Analisa was very aware and understand the role of husband in Islamic households so however the situation, she was still positioning her husband as the last authority holder in the household, for example in terms of permission to work outside the home. Without permission from her husband, all efforts to optimize her career and potential become worthless. Thus having an authority's position outside the domestic realm remains in second place after the 'natural' role of women as mother and wife. So, the men's role would still be guaranteed even the women's economic capacity, as well as wives, has increased.

Although it still positions young Muslim women as productive subjects, it may be seen as subverting gender expectations in Indonesian women (Sakai and Fauzia, 2016c, p. 236). Unlike Robbie (2009a, pp. 124-125) who considers this phenomenon more likely to be part of the current 'women's movement'. However, this 'women's movement' is not promoting progressive feminist goals. The 'women's movement' started from a modernity form through the new and different femininity reason from the previous one that appeared among Muslim women, especially Muslim influencers in Indonesia. Agreeing to this, Robbie recalls the idea of 'progress' being used by young women's employment involvement in the workforce and economic activities encouraging them to get a requiring room for special features of 'female citizenship'. She called it a 'women's movement' and refers to a women's need, especially those under the age of 50, and still have the potential to involve the labor market or move forward as participants and active consumers. Both activities, work and shopping, have become the hallmarks of the new trend of female citizenship in Indonesia today (Robbie, 2009a, p. 124). 
Thus, the acceptance of modernity and religious understanding embraced by Analisa gave her perspective in realizing the reason for new femininity which ultimately formed a new trend in addressing social life from all aspects. This reason then actively and creatively establishes how young Muslim women's appearance, behavior, and ideals should look like in a personal, social, and political space, including the production of various leisure activities. It is also made easier by mediating the prevalence of various social media platforms that play a role in bridging and channeling all of them.

\section{Conclusion}

The early Islamic studies was focused on the study of influencers and 'impromptu' artists who have emerged as a result of technological developments have always focused on the inevitability of economic goals, where the styles and identities of influencers and artists are nothing more than just to serve their satisfaction in achieving financial benefits. However, the facts revealed in this study are actually able to provide other interesting facts from an ideological perspective. This study does not negate material goals, but rather shows the ideological side of the development of these material goals which can be seen explicitly through the various daily activities of influencers on their various social media, especially Instagram.

The new style of identity and aspirations from the displaying of new Muslim middle-class through the representation of Muslim influencers on social media become concrete evidence of the digital media development and the attempt to negotiate a religious understanding of popular culture in the use of leisure time today. The difference in orientation of religious understanding gives rise to segmentation that inevitably occurs and manifests in every action, even becoming a lifestyle trend today. The distribution of leisure time becomes a 'padded' new discourse to insert certain ideas of Muslim influencers while still using the Muslim identity as a supporting instrument.

In the end, this study was intended to further open the horizons and awareness of social media connoisseurs who always feel 'enchanted' by ideas and invitations from influencers to do something or buy an item, even believe in an ideological understanding, so that they can judge wisely and do some through research before following what the influencers suggest. Given, the strength of the micro-celebrities who are their capital in "promotion" has quite an extraordinary appeal. The last but not least, this study was recommended several things about research that can be developed further, including the consequences and specific forms of leisure time of actors and social agents in society other than influencers who are now have quite influential in religious understanding. In addition, this study can also be a 'crossing bridge' to connect further research by enriching the scientific treasures related to the discussion of leisure time and the new Muslim middle-class in this era of information disruption.

\section{References}

\section{Books, Book Section, and Article Journal:}

A’isyah, A'isyah \& Aini, Rezki Putri Nur. (2020a). Media Representation Of Muslimah Influencer In Frame Of Dakwah| INOVATIF: Jurnal Penelitian Pendidikan, Agama dan Kebudayaan. Vol. 6 No. 2. http://jurnal.staih.ac.id/index.php/inovatif/article/view/167 
Abdurrahman, Moeslim. (2009b). Bersujud di Baitullah: Ibadah Haji, Mencari Kesalehan Hidup. Penerbit Buku Kompas.

Abidin, Crystal. (2016a). Visibility Labour: Engaging with Influencers' Fashion Brands and \#OOTD Advertorial Campaigns on Instagram. Media International Australia 161, (1).

Addini, Agnia. (2019a). Fenomena Gerakan Hijrah di Kalangan Pemuda Muslim Sebagai Mode Sosial. Journal of Islamic Civilization, Vol. 1, No. 2.

Annisa, Firly. (2018b). Hijrah Millenial: Antara Kesalehan dan Populism. Ma'arif Institute, Vol. 13(No. 1).

Barlas, Asma. (2001). The Qur'an and Hermeneutics: Reading the Qur'an's Opposition to Patriarchy. Edinburgh University Press, Vol. 3, No. 2.

Baulch, Emma \& Parmiyanti, Alila. (2018a). Hijabers on Instagram: Using Visual Social Media to Construct the Ideal Muslim Woman. SAGE, Social Media + Society.

Bayat, Asef. (2007a). Islam and Democracy: What is the Real Question? Amsterdam University Press.

Bayat, Asef. (2007b). Islamism and the Politics of Fun. Public Culture, 19 (3). https://doi.org/10.1215/08992363-2007-004.

Beng-Huat, Chua. (2000b). Consumption in Asia: Lifestyles and Identities. The New Rich in Asia.

Beta, Annisa R. (2019b). Commerce, Piety and Politics: Indonesian Young Muslim Women's Group as Religious Influencers. SAGE, New Media and Society.

Braidotti, Rosi. (2002b). Cyberfeminism with a difference. Rowman \& Littlefield Publishers.

Brenner, Suzanne. (1996). Reconstructing Self and Society: Javanese Muslim Women and the Veil. American Ethnologist, 23 (4).

Cevik, Neslihan. (2016d). Muslimism in Turkey and Beyond: Religion in the Modern World. Palgrave Macmillan.

Chaplin, Charlie. (1936). Tempos Modernos (Modern Times) [Drama Komedi]. Dominio Publico.

Deeb, Lara \& Harb, Mona. (2013c). Leisurely Islam: Negotiating Geography and Morality in Shi'ite South Beirut. Princeton University Press.

Embong, Abdul Rahman. (2002a). State-led Modernization and the New Middle Class in Malaysia. Palgrave Macmillan.

Fischer, Johan. (2011). Proper Islamic Consumption: Shopping among the Malays in Modern Malaysia (Book Reviews). American Anthropological Association, Vol. 113(No. 1).

Grenny, Joseph. (2013b). Influencer: The New Science of Leading Change (Second Edition). McGraw-Hill Education. 
Hasan, Noorhaidi. (2009c). The Making of Public Islam: Piety, Agency, and Commodification on the Landscape of the Indonesian Public Sphere. Springer.

Hasbullah, Moeflich. (2000c). Cultural Presentation of the Muslim Middle Class in Contemporary Indonesia. STUDIA ISLAMIKA: Indonesia Journal for Islamic Studies, Vol. 7 No. 2.

Heryanto, Ariel. Translated by Eric Sasono. (2015a). Identitas dan Kenikmatan: Politik Budaya Layar Indonesia. KPG (Kepustakaan Populer Gramedia).

Hine, Christine. (2000a). Virtual Ethnography. SAGE Publication Ltd.

Hunnicutt, Benjamin K. (2006). The History of Western Leisure. A Handbook of Leisure Studies.

Kailani, Najib \& Sunarwoto. (2019d). Televangelisme Islam dalam Lanskap Otoritas Keagamaan Baru. In Ulama dan Negara-Bangsa: Membaca Masa Depan Islam Politik di Indonesia, Penyunt. Noorhaidi Hasan. Pusat Pengkajian Islam, Demokrasi, dan Perdamaian (PusPIDeP).

Kailani, Najib. (2020b). (Ed.), Articulations of Islam and Muslim Subjectivity: Fundamental Debates in the Anthropology of Islam. In Commerce, Knowledge, and Faith: Islamization of the Modern Indonesian and Han-speaking Muslim Ummahs. Center for Multicultural Studies, College of Liberal Arts.

Khumairoh, Izmy. (2018c). Instadakwah: Redefinisi Kesalehan Perempuan Muslim di Bandung Lewat Mediatisasi Ajaran Agama Islam di Instagram. Jurnal Universitas Gadjah Mada, IV/3.

Kim, Seung-Kuk. (2000d). Changing Lifestyles and Consumption Patterns of the South Korean Middle Class and New Generations. Consumption in Asia: Lifestyles and Identities.

Kozinets, Robert V. (2009d). Netnography: Doing Ethnographic Research Online. SAGE Publication Ltd.

Mariampolski, H. (1999). The Power of Ethnography. International Joural of Market Research, $X I / 1$.

Martin, William H. \& Mason, Sandra. (2004). Leisure in an Islamic Context. Taylor \& Francis, No. 1(Philosphy of Leisure).

McRobbie, Angela. (2009a). The Aftermath of Feminism: Gender, Culture and Social Change. SAGE Publication.

Mietzner, Marcus \& Muhtadi, Burhanuddin. (2018d). Explaining the 2016 Islamist Mobilisation in Indonesia: Religious Intolerance, Militant Groups and the Politics of Accommodation. Asian Studies Review, Vol. 42 (3).

Nancy, K Baym. \& Danah, Boyd. (2012). Socially Mediated Publicness: An Introduction. Journal of Broadcasting \& Electronic Media, Vol. 56, No. 3.

Rakhmani, Inayah. (2016b). Mainstreaming Islam in Indonesia: Television, Identity, and the Middle Class. Palgrave Macmillan. 
Raun, Tobias. (2018f). Capitalizing Intimacy: New Subcultural Forms of Micro-Celebrity Strategies and Affective Labor on YouTube. London: SAGE Publication, Vol. 24, No. 1.

Ridho, Subkhi. (2017). Kelas Menengah Muslim Baru dan Kontestasi Wacana Pluralisme di Media Sosial. Vol. 4, No. 2(Jurnal Pemikiran Sosiologi).

Ridho, Subkhi. (2018e). Pesan Instant Muslimah Kelas Menengah Baru: Studi Identitas Islam di Group Whatsapp 'Islam'. Ma'arif Institute, Vol. 13, No. 1.

Rofhani, Rofhani. (2013d). Budaya Urban Muslim Kelas Menengah. Teosofi: Jurnal Tasawuf Dan Pemikiran Islam, Vol. 3(No. 1).

Sakai, Minako \& Fauzia, Amalia. (2016c). Performing Muslim Womanhood: Muslim Business Women Moderating Islamic Practices in Contemporary Indonesia. Islam and ChristianMuslim Relations, Vol. 27(3).

Sakai, Minako. (2014a). Establishing Social Justice Through Financial Inclusivity: Islamic Propagation by Islamic Savings and Credit Cooperatives in Indonesia. TRANS: TransRegional and National Studies of Southeast Asia, Vol. 2(Issue 02).

Wallman, Sandra. (1979). Social Anthropology of Work. Academic Press.

Ward, Pete. (2020c). Celebrity Worship. Routledge: Taylor \& Francis Group.

Wieringa, Saskia Eleonora. (2015b). Gender Harmony and The Happy Family: Islam, Gender and Sexuality in Post- Reformasi Indonesia. South East Asia Research 23 (1).

Wynne, Derek. (1998). Leisure, Lifestyle and the New Middle Class: A Case Study. Routledge: Taylor \& Francis Group.

Yusuf, Muhammad Fahrudin. (2019c). Dakwah Simbolik Hijrah dan Moderasi Islam di Media Online. Jurnal Aqlam: Journal of Islam and Plurality, Vol. 4, No. 2.

\section{Website and Social Media:}

(431) Analisa Channel-YouTube. (2020). Retrieved 1 September 2020, from https://www.youtube.com/user/analisa431

Analisa Personality Development Center (APDC) | LinkedIn. (n.d.). Retrieved 1 September 2020, from https://id.linkedin.com/company/analisa-personality-development-center-apdc

Analisa Widyaningrum (@analisa.widyaningrum) - Instagram photos and videos. (n.d.). Retrieved 3 January 2021, from https://www.instagram.com/analisa.widyaningrum/

Anandito Dwis. (2020). In Wikipedia bahasa Indonesia, ensiklopedia bebas. https://id.wikipedia.org/w/index.php?title=Anandito_Dwis\&oldid=17305785

AnanditoDwis (@ananditodwis)•Instagram photos and videos. (2020). Retrieved 3 January 2021, from https://www.instagram.com/ananditodwis/ 
AnisaRahmaAdi (@anisarahma_12)•Instagram photos and videos. (2020). Retrieved 3 January 2021, from https://www.instagram.com/anisarahma_12/

Anisa Rahma dan Anandito Menikah, Hubungan Berawal dari Proyek Singlelillah. (2018). Tribun Jabar. Retrieved 28 June 2020, from https://jabar.tribunnews.com/2018/09/17/anisarahma-dan-anandito-menikah-hubungan-berawal-dari-proyek-singlelillah

Biografi Anisa Rahma mulai dari Masa Kecil, Karir hingga Kehidupan Pribadi-WowKeren.com. (2020). $\quad$ Retrieved $17 \quad$ September 2020, from https://www.wowkeren.com/seleb/anisa_rahma/bio.html

Carrieri, Alexandre de Padua; Diniz, Ana Paula Rodrigues; de Souza, Elolslo Moulin \& Menezes, Raquel Santos Soares. (2013a). Gender and Work: Representations of Femininities and Masculinities in the View of Women Brazilian Executives. Http://Www.Anpad.Org.Br/Bar, Vol. 10(No. 3).

Dari Seksi sampai Berhijab, 6 Transformasi Anisa Rahma Eks Cherrybelle-MataMata.com. (2020). Retrieved 3 January 2021, from https://www.matamata.com/life/2019/10/12/201500/dari-seksi-sampai-berhijab-6transformasi-anisa-rahma-eks-cherrybelle

Femalepreneur Indonesia. (n.d.). Retrieved 1 September 2020, from https://femalepreneur.id/intip-12-influencer-perempuan-berpengaruh-di-indonesia

Kisah Analisa Widyaningrum, Psikolog Cantik yang Bertekad Kembangkan Kepribadian Kaum Milenial | jadiberita.com. (2017, November 19). https://jadiberita.com/120924/kisahanalisa-widyaningrum-psikolog-cantik-yang-bertekad-kembangkan-kepribadian-kaummilenial.html

Kompasiana.com. (2013, April 14). Apa itu Muslim yang Kaffah? KOMPASIANA. https://www.kompasiana.com/nanangrosidi/552b835e6ea834767d8b456e/apa-itumuslim-yang-kaffah

Media, Kompas Cyber. (2020). Girlband Cherrybelle Reunian dari Rumah Masing-masing, ke Mana Sarwendah? Halaman all. KOMPAS.com. Retrieved 18 September 2020, from https://www.kompas.com/hype/read/2020/04/16/171054566/girlband-cherrybellereunian-dari-rumah-masing-masing-ke-mana-sarwendah

Putri, S. (2020). Ayu Tenan, Ini Potret Psikolog Cantik Berhijab asal Yogyakarta. wolipop. Retrieved 18 September 2020, from https://wolipop.detik.com/foto-hijab/d-4168941/ayutenan-ini-potret-psikolog-cantik-berhijab-asal-yogyakarta

Sarah Sechan-Analisa Widyaningrum Inspirator Muda penerima beasiswa Djarum. (2013). Retrieved 1 September 2020, from https://www.youtube.com/watch?v=uC8FLFJjvyc

Sulistyawati, Rr Laeny \& Sasongko, Agung. (2014b, Oktober). Empat Tipe Konsumen Kelas Menengah Muslim di Indonesia [Berita Ekonomi]. Republika. https://republika.co.id/berita/ekonomi/syariah-ekonomi/14/10/26/ne298r-empat-tipekonsumen-kelas-menengah-muslim-di-indonesia 